\title{
Heat distribution modeling of the subsurface of Wapsalit geothermal area based on land surface temperature from Landsat-8 thermal infrared sensor imagery
}

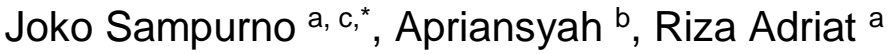 \\ a Department of Physics, Faculty of Mathematics and Natural Sciences, Tanjungpura University, Jl. Prof. Dr. H. Hadari Nawawi, Pontianak, Indonesia, \\ 78124 \\ ${ }^{b}$ Department of Marine Sciences, Faculty of Mathematics and Natural Sciences, Tanjungpura University, Jl. Prof. Dr. H. Hadari Nawawi, Pontianak, \\ Indonesia, 78124 \\ ${ }^{c}$ Earth and Life Institute, Université catholique de Louvain, Croix du Sud, 2 bte L7.05.16, B-1348 Louvain-la-Neuve, Belgium
}

* Corresponding author: jokosampurno@physics.untan.ac.id

\section{Article history}

Received 24 January 2018

Revised 28 March 2018

Accepted 20 May 2018

Published Online 14 April 2019

\begin{abstract}
In this research, models of heat distribution of the subsurface of the Wapsalit geothermal area were built, which their structures were known before, using finite different method. Rock thermal diffusivity was used as the model parameter, which controlled the heat flow. The result showed that the heat flow was adjusted the model parameters effectively. Land surface temperature (LST) as the result of the model was compared to LST from Landsat-8 thermal infrared sensor imagery and produced absolute error $6.8 \%$ and $3.6 \%$ for cross-section 1 and 2 , respectively. This error percentage confirmed that the model was successfully depicted the actual heat distribution of the subsurface of the study area.
\end{abstract}

Keywords: Heat distribution, Landsat-8 TIRS, Wapsalit geothermal area

(c) 2019 Penerbit UTM Press. All rights reserved

\section{INTRODUCTION}

Appropriate inversion of geophysical variables from remote sensing imagery for geothermal survey applications is extremely important and challenging issue. This issue is becoming important because remote sensing data is easy and free to be accessed. The data is also updated frequently. Nowadays, LST of an area can be obtained from the space using Landsat-8 Thermal Infrared Sensor Imagery (TIRS). In geothermal inverse modelling, the LST can be used as the observation data which will be fitted using LST model. LST models are obtained from heat transfer modelling of a geothermal area.

A geothermal system is basically a system where heat is transferred from the reservoir to the land surface through conduction or convection process (Putra et al., 2014). This mechanism can be used to investigate the structure which is passed by the heat using inversion method. Yet, the inversion method can be successfully applied if there is a suitable model in the forward modelling step.

In this study, models of heat distribution of the subsurface of Wapsalit geothermal areas were built using finite different methods. The structures of the study area were known before. As the model parameter, which would control the heat flow, thermal diffusivity of the subsurface rocks was used. Furthermore, LST from the model was fitted by LST from Landsat- 8 TIRS. The model would be declared as successful if the fitting could produce a minimum error.

\section{LITERATURE REVIEW}

Remote sensing is a method to photograph the condition of the earth's surface based on satellite images. The remote sensing method has been applied in many kinds of research such as forest degradation study (Jean-fiston et al., 2016), landfill characterization (Beaumont et al., 2014) etc. The newest satellite, which performs this function, is Landsat-8. Landsat 8 was launched by NASA in 2013. Two main sensors which equipped with the satellite are TIRS and Operational land Imager (Irons et al., 2012). TIRS is used to map earth's surface temperature, while OLI is used to map earth's surface contours.

In the geothermal exploration, remote sensing becomes one of the most promising technologies to be applied. This technology is considered as promising because the imagery data is available for free and frequently updated. The application of this technology has been initiated by (Huntington, 1996).

\section{EXPERIMENTAL}

\section{Land surface temperature (LST) data}

Data used in this study was LST of Wapsalit Geothermal Area (Fig 1). This area was located at Maluku, Indonesia, which its coordinate was: $126^{\circ} 47^{\prime} 40^{\prime \prime}-126^{\circ} 56^{\prime} 47^{\prime \prime} \mathrm{E}$ and $3^{\circ} 34^{\prime} 16^{\prime \prime}-3^{\circ} 26^{\prime} 09^{\prime \prime} \mathrm{S}$. This study used Landsat 8 TIRS imagery, which was acquired on February 6, 2015, on thermal bands 10 and 11. The data was downloaded from (USGS, 2017). Recording sheets used were Path 110 and Raw 62 (covering the Maluku region). Digital analysis method was applied to extract the reflection values of the paths, which numeric digits would become radiance values. This information was stored in numeric digits ranged from 0 - 65536 on the Landsat 8 TIRS satellite. Extraction was done by changing the digit number to the value of radiance. The radiance value of the thermal spectrum was affected by the heat of the surface of the earth. The higher the earth's surface heat, the higher the radiation intensity. 


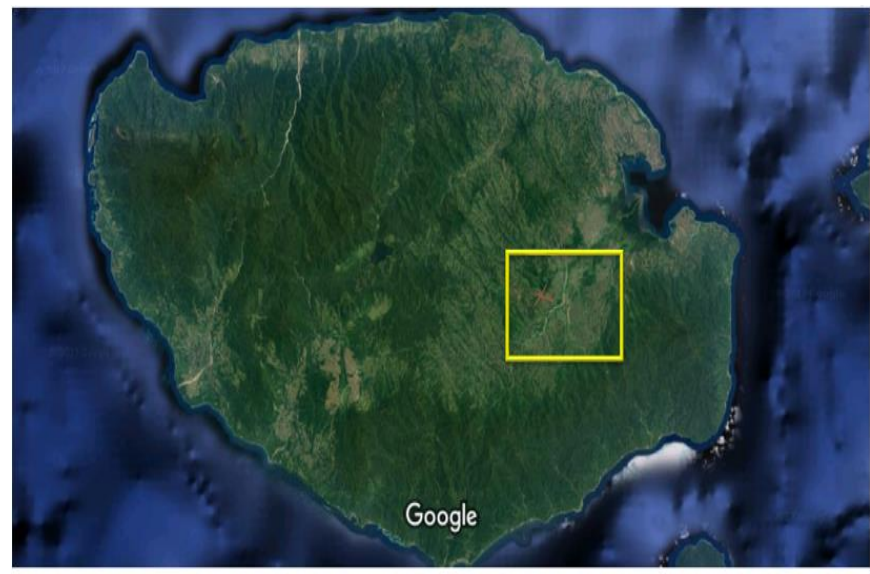

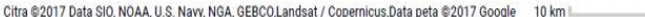

Fig. 1 Wapsalit geothermal area (Yellow square was the area study).

Next, the value of radiance was converted to radial spectra through radiometric correction. This radiometric was chosen because it could affect the spectral reflection of an object. The correction was applied to get the value of radiance which was close to the real LST. The radiance spectral value was converted to LST (in the Kelvin scale) through the following equation (Hoffmann \& Chiang 1989) :

$$
T=\frac{K_{2}}{\ln \left(\frac{K_{1}}{C V R}\right)+1}
$$

Where:

$T \quad=$ Corrected Temperature

$C V R=$ Radiance spectral value

$T_{1}$ and $T_{2}=$ Coeffecient of Thermal band

LST (on the Kelvin scale), as the product of the previous conversion, was then converted again to the LST on the Celsius scale. The LST as the output of the process could be seen in Fig. 2.

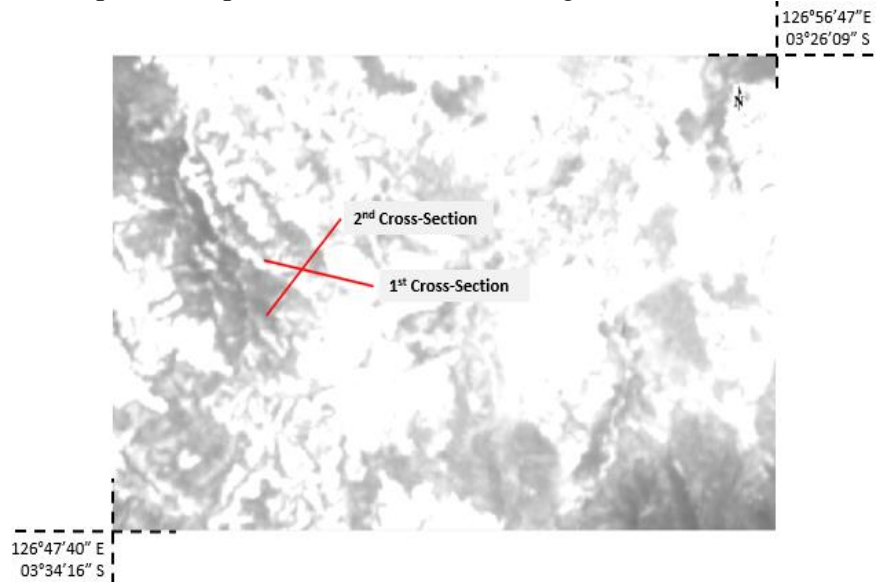

Fig. 2 LST of the Wapsalit geothermal area (obtained from Landsat-8 imagery) and cross-section which were used in the modelling.

\section{Modelling}

Next step, a numerical modelling of heat transfer in the Wapsalit geothermal area was built which its structure was known. The subsurface structure of this area was investigated using Magnetotelluric method (Fitrida et al., 2015). The structure was interpreted from its resistivity distribution.

Wapsalit geological models (Fig. 3) were created based on previous study (Fitrida et al., 2015). These models depicted the rock structure of the area.

The model in Fig. 3a (1st cross-section) has dimensions of $35 \mathrm{x} 40$ grid nodes (representing $3500 \mathrm{~m} \times 4000 \mathrm{~m}$ actual size), while the model in Fig. 3b (2nd cross-section) has dimensions of $26 \times 40$ grid nodes (representing $2600 \mathrm{~m} \times 4000 \mathrm{~m}$ actual size). Colors within the cells in Fig. 3 were referred to: Sandy Soil (gray), Granite (blue), Shale (yellow) and Limestone (green) (Minkowycz et al., 2009).
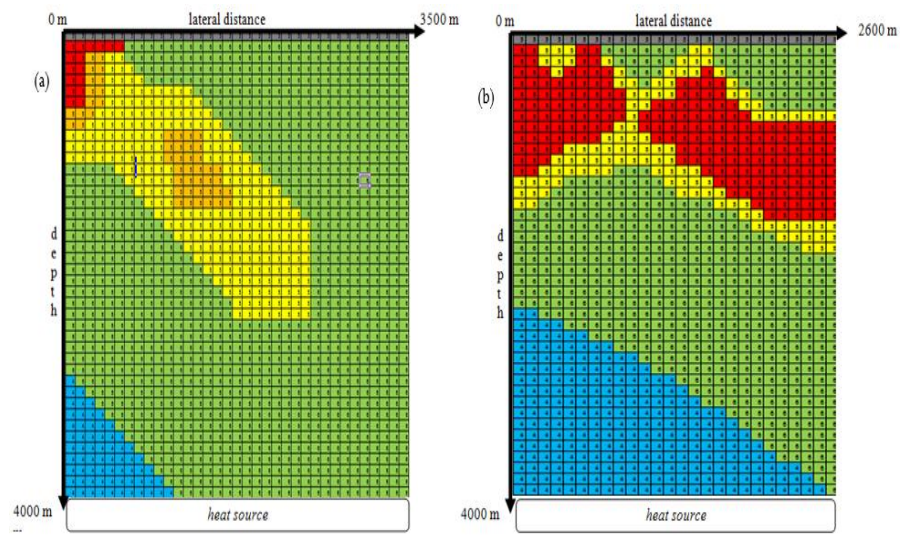

Fig. 3 Simple Models for Wapsalit Geological Models: (a) $1^{\text {st }}$ crosssection; (b) $2^{\text {nd }}$ cross-section.

To simulate the heat transfer process, the equation of $2 \mathrm{D}$ heat conduction in an unsteady state form was used and given by (Minkowycz et al., 2009):

$$
\frac{\partial \mathrm{T}}{\partial \mathrm{t}}=\kappa\left(\frac{\partial^{2} \mathrm{~T}}{\partial \mathrm{x}^{2}}+\frac{\partial^{2} \mathrm{~T}}{\partial \mathrm{z}^{2}}\right)
$$

And:

$$
\kappa=k / \rho c_{p}
$$

Where:

$\kappa:$ Coefficient of the thermal diffusivity $\left(\mathrm{m}^{2} / \mathrm{s}\right)$

$k$ : Thermal conductivity of rock $(\mathrm{W} / \mathrm{mK})$

$\rho:$ Density of the fluid/the rock $\left(\mathrm{kg} / \mathrm{m}^{3}\right)$

$c_{p}:$ Specific heat capacity $(\mathrm{kJ} / \mathrm{kg})$

The Equation (2) could be solved by using the implicit finite difference method, which in this case the Crank-Nicholson Algorithm was used to produce the solution in $\mathrm{x}$-direction and $\mathrm{y}$-direction (Sampurno et al., 2017). The solution in $x$-direction was given by (Hoffmann \& Chiang 1989):

$$
\begin{gathered}
\frac{\kappa_{i, j} \Delta t}{4 \Delta x^{2}} T_{i-1, j}^{n+\frac{1}{2}}+\left(1+2 \frac{\kappa_{i, j} \Delta t}{4 \Delta x^{2}}\right) T_{i, j}^{n+\frac{1}{2}}+\frac{\kappa_{i, j} \Delta t}{4 \Delta x^{2}} T_{i+1, j}^{n+\frac{1}{2}}=T_{i, j}^{n}+\frac{\kappa_{i, j} \Delta t}{4 \Delta x^{2}}\left(T_{i+1, j}^{n}-\right. \\
\left.2 T_{i, j}^{n}+T_{i-1, j}^{n}\right)
\end{gathered}
$$

The solution in y-direction was given by:

$\frac{\kappa_{i, j} \Delta t}{4 \Delta y^{2}} T_{i, j-1}^{n+1}+\left(1+2 \frac{\kappa_{i, j} \Delta t}{4 \Delta y^{2}}\right) T_{i, j}^{n+1}+\frac{\kappa_{i, j} \Delta t}{4 \Delta y^{2}} T_{i, j+1}^{n+1}=T_{i, j}^{n+\frac{1}{2}}+$

$\frac{\kappa_{i, j} \Delta t}{4 \Delta y^{2}}\left(T_{i, j+1}^{n+\frac{1}{2}}-2 T_{i, j}^{n+\frac{1}{2}}+T_{i, j-1}^{n+\frac{1}{2}}\right)$

\section{RESULTS AND FINDINGS}

Fig. 4a and 5a show the numerical modeling results of the Wapsalit Geothermal area for 1st cross-section and 2nd cross-section, respectively. In the both models, the heat was set to flow from bottom (the reservoir layer) to the earth's surface. The reservoir was set at higher temperature than surrounding due to direct contact with the heat sources, suspected from magma intrusions. The heat distribution patterns of both models indicated that the heat was spreaded by adjusting to the rock thermal diffusivity.

From the Fig. 4a, The LST of the 1st cross-section was recorded by digitizing the model temperature at the zero depth (model surface area). This LST was then compared to the LST from Landsat-8 imagery (Fig. $4 \mathrm{~b}$ ), producing absolute error of $6.8 \%$. This error percentage confirmed that the model could describe the real heat pattern in the subsurface accurately. 
(a)

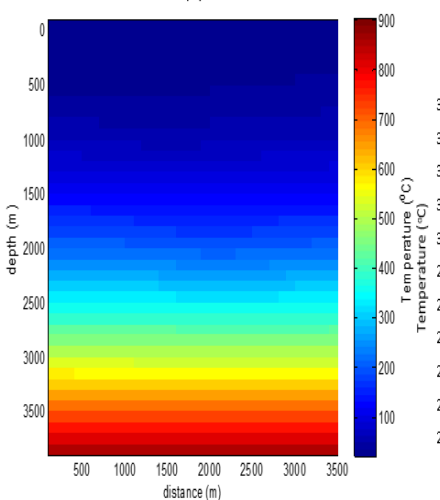

(b)

Landsat- 8 model

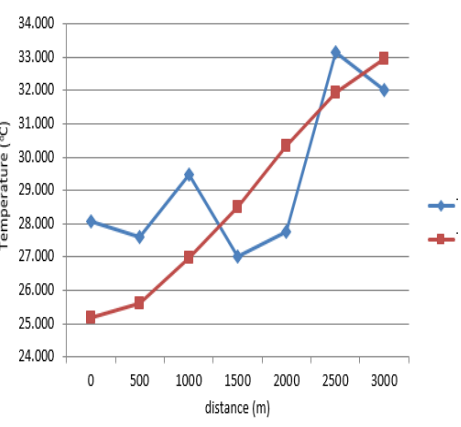

Fig. 4 (a) $1^{\text {st }}$ Cross-Section thermal distribution model at the Wapsalit geothermal area; (b) LST profile of the model (red) compared to LST of landsat-8 imagery (blue).

As the previous procedure, the LST of the 2nd cross-section was also recorded and compared to the LST from Landsat-8 imagery (Fig. $5 b)$. This comparison produced absolute error of 3.6\%. This error percentage confirmed that the model was well-depicted the real heat distribution in the subsurface. It also showed that this model was better than the 1st model. Since both models could depict the actual temperature of the study area, it could be summed up that the $2 \mathrm{D}$ heat conduction equation could be used as one of the forward modelling schemes in geothermal inverse modelling.

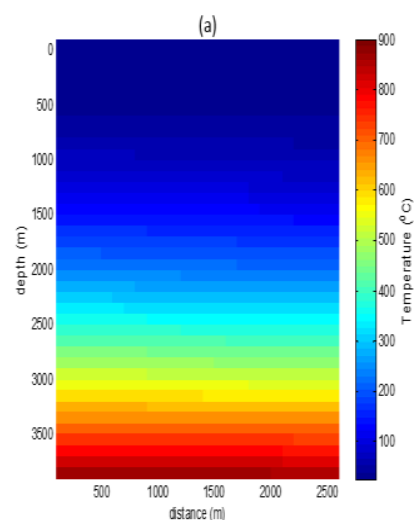

Fig. 5 (a) 2nd Cross-Section thermal distribution model at the Wapsalit geothermal area; (b) LST profile of the model (red) compared to LST of landsat-8 imagery (blue).

\section{CONCLUSION}

The heat flow model, which was created and based on the finite difference implicit method, has successfully modeled the distribution of the heat at the Wapsalit geothermal area. LST as the result of the model was compared to LST from Landsat- 8 Thermal Infrared Sensor Imagery, producing absolute error of $6.8 \%$ and $3.6 \%$ for cross-section 1 and 2 , respectively. These errors confirmed that the model could successfully depict the real heat distribution in the Wapsalit Geothermal area.

\section{ACKNOWLEDGEMENT}

This research work was supported by the Insentif Riset Sistem Inovasi Nasional (INSINAS) Program held by Directorate General of Strengthening Research and Development, Ministry of Research, Technology and Higher Education (Indonesia), in accordance with Contract Number 37/INS/PPK/E/E4/2017, dated May 26th, 2017.

\section{REFERENCES}

Beaumont, B., Radoux, J., Defourny, P. 2014. Assessment of airborne and spaceborne thermal infrared remote sensing for detecting and characterizing landfills. WIT Transactions on Ecology and the Environment, 180, 1-12.

Fitrida, S. M., Sampurno, J., Ivansyah, O., Kholid, M. 2015. Identifikasi struktur bawah permukaan berdasarkan metode magnetotellurik. Positron, 5, 1, 11-18.

Hoffmann, K. A., Chiang, S. T. 1989. Computational fluid dynamics for engineers. 4th ed. Austin: TX: Engineering Education System.

Huntington, J. F. 1996. The role of remote sensing in finding hydrothermal mineral deposits on earth. Paper presented at the Ciba Foundation symposium. 202, 214-231.

Irons, J. R., Dwyer, J. L., Barsi, J. A. 2012. The next landsat satellite: The landsat data continuity mission. Remote Sensing of Environment, 122, 11-21.

Jean-fiston, M. N., Gossens, R., Defourny, P. 2016. Forest degradation, a methodological approach using remote sensing techniques: A review. International Journal of Innovation and Scientific Research, 24, 1.

Minkowycz, W., Sparrow, E. M., Murthy, J. Y., Abraham, J. P. 2009. Handbook of Numerical Heat Transfer: $2^{\text {nd }}$ Edition: John Wiley \& Sons, Inc.

Putra, S. D. H., Fajar, S. J., Srigutomo, W. 2014. Numerical modeling of $2 D$ conductive heat transfer and its application for the characterization of geothermal systems. Paper presented at the 2014 International Conference on Physics (ICP 2014).

Sampurno, J., Apriansyah, Adriat, R., Faryuni, I. D., Srigutomo, W. 2017. Application of implicit finite difference method to determine the 2D patterns of unsteady state thermal spreading of geothermal systems. Journal of Physics: Conference Series, 877, 1, 012012.

USGS. 2017. Pulau buru. Retrieved from https://earthexplorer.usgs.gov/ (Accessed: March 21, 2017). 